\section{«Point-of-care»-ultralyd - av interesse for mange!}

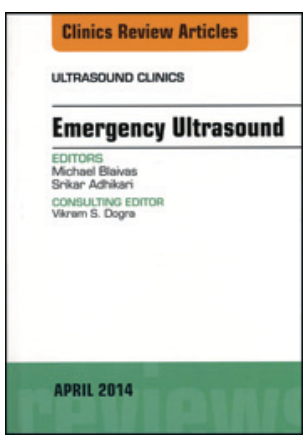

Michael Blaivas, Srikar Adhikari, red. Emergency ultrasound

Ultrasound clinics. 312s, tab, ill. Philadelphia, PA:

Elsevier, 2014. Pris GBP 63

ISBN 978-0-3232-9020-3
Emergency ultrasound er nummer 2 (2014) i en serie med fire årlige utgivelser, skrevet for helsepersonell som i en eller annen form arbeider med eller har interesse for ultralyd. Boken er i A5-format og består av 12 selvstendige artikler/kapitler.

I forordet beskriver redaktørene den enorme bredden ultralyd har fătt innen akuttmedisin. De beskriver begrepet «point-of-care»ultralyd - med fokus både på diagnostisk støtte og på nytten ultralyd har ved prosedyrer.

Alle artiklene er frittstående, de har forskjellige forfattere og omhandler ultralydens ulike bruksområder. Det gjør det greit å forholde seg til en og en artikkel. Boken i sin helhet preges av en god del overlapping, men i et slikt format er dette uproblematisk.

Når man diskuterer begrepet «point-of-care»-ultralyd, er det helt sentralt å knytte klinikk til ultralydfunn; det skal være klinikerens verktøy for en bedre diagnostisk presisjon. Boken illustrer dette på en mesterlig måte. Den fokuserer på kliniske problemstillinger og gjør rede for hvordan ultralyd (på en lite ressurskrevende måte) kan hjelpe oss videre mot målet. Det er rikelig med tabeller som fokuserer på kliniske funn og ultralydfunn, noe som gjør artiklene lettleste. Begrepene «pearls and pitfalls» går igjen i alle artiklene, samt gjenfinnes i egne tabeller. Dette er et godt pedagogisk grep, og i mine øyne svært nyttig.

Det finnes rikelig med fine illustrasjoner/bilder, både bilder som viser hvordan man korrekt gjør de forskjellige opptakene, og en rekke illustrasjoner av både normalanatomi og patologi. Illustrasjonene er jevnt over av svært god kvalitet. Jeg har særlig kritisk vurdert de illustrasjonene som omhandler kardiologirelaterte undersøkelser, og finner at disse er korrekte og i tråd med gjeldende retningslinjer. Ultralyd er jo i all hovedsak «looper» (video), ikke stillbilder. Det er mulig å logge seg inn på nettsiden www.ultrasound.theclinics.com for å se videoene. Dette virker greit hvis du abonnerer på serien, men ikke fullt så greit om du kun har gått til innkjøp av denne enkeltutgivelsen.

Vil man tyngre inn i materien, inneholder hver artikkel en rekke sentrale referanser.

Boken representerer en samling av relevante, godt skrevne og rikt illustrerte artikler innenfor det raskt voksende feltet «point-ofcare»-ultralyd. Det er en bok man ikke vil lese fra perm til perm, men som vil være et nyttig oppslagsverk for de etter hvert mange klinikerne som har valgt å ta ultralyd inn som en del av hverdagen.

Ole Christian Mjølstad

Overlege, Klinikk for hjertemedisin

St. Olavs hospital

\section{Fargerik ultralyd av muskel og skjelett}

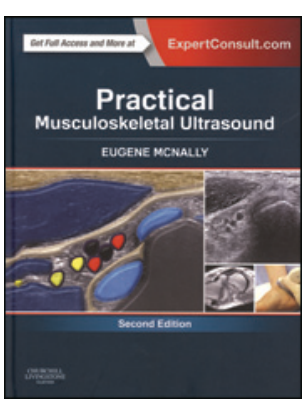

Eugene McNally Practical musculoskeletal ultrasound

2. utg. 440 s, ill. Edinburgh: Churchill Livingstone Elsevier, 2014. Pris GBP 123 ISBN 978-0-7020-4377-0

Radiologisk litteratur har det siste tiåret utviklet seg fra noen få standardverk til et bredt utvalg bøker og e-bøker med hyppige revideringer. Årsaken kan ligge i utviklingen av faget, med økt krav til subspesialisert og oppdatert kunnskap, men også i at andre faggrupper har begynt å bruke radiologi som verktøy.

Practical musculoskeletal ultrasound lokker med solid innbinding, fargebilder og video i elleve kapitler, fra skulder til forfot samt et par generelle kapitler.

Fra start til mål gjennomgås systematisk ledd og ekstremiteter, normalanatomi, de vanligste patologiske tilstandene og hvordan de fremstår på ultralyd, vist med bilder i svarthvitt og med forklarende fargelegging. E-delen som følger boken, har i tillegg små videoklipp med typiske funn ved patologi.

Utgangpunktet skulle derfor være det beste for at denne boken kan være et supplement til praktisk opplæring under veiledning og et volum av undersøkelser for å oppnå ferdigheter og forståelse for det som skal undersøkes.

I stor grad innfrir boken, med grundig tekstgjennomgang, bilder som viser gjennomføring av undersøkelsen, og ultralydbildene ved siden av hverandre. Ved dypdykk blir imidlertid førsteinntrykket noe justert. Ikke alle ultralydbildene er like skarpe, og det er en utstrakt bruk av forkortelser som det tar litt tid å finne forklaringen på.

E-boken består i tillegg av usorterte 111 videosnutter på 18 sekunder. De gir en viss innsikt i den dynamiske karakteren av en undersøkelse, men er ikke lette å forstå da de er korte og mangler forklarende tekst.

Boken inneholder ingen generell basal innføring i muskel og skjelett sonoanatomi og teknikk. Den egner seg derfor ikke for lesere uten grunnkunnskaper.

For den som allerede har litt generell bakgrunn i ultralyd, er temaet presentert oversiktlig og med mange praktiske tips til hvordan undersøkelsen kan gjøres for å fremstille vanskelige områder bedre. Sammenstillingen av to tilsvarende ultralydbilder der det ene har forklarende fargelegging, gjør at det er lett å forstå bildene.

Practical musculoskeletal ultrasound er en fargeklatt som kan brukes i opplæring for å forklare typiske normale snittbilder og typiske funn ved patologi i muskel- og skjelettsystemet.

Hvis man skal kjøpe kun én bok om muskel-skjelett-ultralyd, er dette kanskje ikke boken å velge, da den verken er en fullstendig oppslagsbok eller så liten at den glir inn i lommen til praktisk bruk.

Annja Viset

Overlege, Klinikk for bildediagnostikk

St. Olavs hospital 